\title{
Causes of intraplate seismicity in Central Brazil from travel time seismic tomography
}

Marcelo Peres Rocha ${ }^{1}$, Paulo Araújo de Azevedo ${ }^{1}$, Martin Schimmel ${ }^{2}$, Reinhardt Fuck ${ }^{1}$

1- Institute of Geociences, University of Brasília, Brasília, DF, Brazil

2- Institute of Earth Sciences "Jaume Almera", Barcelona, Spain

Copyright 2014, SBGf - Sociedade Brasileira de Geofísica

Este texto foi preparado para a apresentação no VI Simpósio Brasileiro de Geofísica, Porto Alegre, 14 a 16 de outubro de 2014. Seu conteúdo foi revisado pelo Comitê Técnico do VI SimBGf, mas não necessariamente representa a opinião da SBGf ou de seus associados. É proibida a reprodução total ou parcial deste material para propósitos comerciais sem prévia autorização da SBGt.

\begin{abstract}
New results of the travel time seismic tomography in Central Brazil allows to discuss the causes of high intraplate seismicity in Tocantins Province. These results provide strong evidences that the seismicity in this region is related to the thinner lithosphere, which limits Amazonic and São Francisco cratonic block. Data from 15 new stations, installed along the GoiásTocantins Seismic Zone, with events recorded during years 2007-2012, were included in a tomographic database used by Rocha et al. (2011), in order to map regions not covered previously, especially the north part of Tocantins Province. The new data allows mapping the upper-mantle beneath Tocantins Province, were São Franciscan and Amazonian Plates are characterized by high velocities anomalies. The transition between these two blocks is marked by low velocity anomalies, and it is well spatially correlated with a high seismicity region, probably related to the rise of asthenosphere and consequent lithospheric thinning.
\end{abstract}

\section{Introduction}

Most of the seismically active regions of the Earth, with the largest earthquakes, coincide with the limits of tectonic plates. Unlike plate boundary regions, where of seismicity is relatively uniform and the causes are well understood, intraplate seismicity represents diffuse deformation in relative stable tectonic regions (Zoback, 1992), and their origins cannot be explained simply, once they are dependent on the local tectonic context.

The most common models proposed to explain the intraplate seismicity are related to pre-existing weakness zones, such as extended crust in aborted rifts or continental margins (e.g. Johnston, 1989; Schulte and Mooney, 2005); or stress concentration in upper crust due structural inhomogeneities (e.g. Sykes, 1978; Talwani, 1989; Talwani and Rajendran, 1991; Kenner and Segal, 2000). Liu \& Zoback (1997) showed that of stress concentration in the upper crust of the New Madrid seismic zone is result of a weaker subcrustal lithosphere. In this way, Assumpção et al. (2004), based in seismic tomographic results, proposed that the lithospheric thinning could be provide favorable conditions for stress concentration in the brittle upper crust, and may explain the epicentral distribution in Brazilian Platform.

In South American continent, the regional stress field is dominated by E-W compression (Zoback, 1992). The origin of this stress regime in South America is mainly due forces related with spreading on the Mid-Atlantic
Ridge and the resistive forces exerted by the Caribbean plate to the north and Nazca plate subduction to the west (Mendiguren \& Richter, 1978; Coblentz \& Richardson, 1996). Intraplate seismicity in Brazil is clearly not uniform and a few areas of higher activity have been identified (Assumpção et al., 2004). An example of the high seismic concentration can be observed in Central Brazil. A significant seismicity, with preferential epicenter distribution in the SW-NE direction, is observed in the Tocantins Province. This is known as Goiás-Tocantins Seismic Zone - GTSZ (Berrocal et al., 1984; Fernandes et al, 1991). The seismicity of Central Brazil may be related to the limits between São Francisco and Amazonian paleoplates, which represent a region of lithospheric thinning. According to Assumpção et al. (2004), in regions of tectonic lithospheric thinning, efforts tend to focus on the crust, while in regions of thicker lithosphere these efforts focus primarily on itself.

In mantle seismic tomography results, lithospheric thinning regions appear as low-velocity anomalies (Assumpção et al, 2004; Zhang et al., 2009; Rocha et al, 2011), which can be interpreted as regions of higher relative temperature. Lithosphere thicker regions, such as cratons, are characterized by stability and lowtemperatures, and normally appears has high-velocity tomographic anomalies.

In this context, our objective was to relate new results of P-wave seismic tomography in Central Brazil with the seismicity distribution in order to help the explanation of the causes of the high seismicity of the GTSZ. Figure 1 shows our study area with stations used. This area is located mostly in the Tocantins Province, and covers the southeastern part of the Amazonian Craton, the western part of the São Francisco Craton and the southern part of the Parnaiba Basin. The Transbrasiliano Lineament, a major lithospheric discontinuity that defines the boundary of different crustal domains (Cordani and Sato, 1999), crosses this area. This area is the same used by Rocha et al. (2011), however the interpreted area was the dashed rectangle, where are located the new stations.

\section{Metodology}

The tomographic method used in this study is based on linear inversion approach of VanDecar et al. (1995), which is based in the inversion method $\mathrm{ACH}$ (Evans and Achauer, 1993). This method has been successfully used in different areas (e.g. VanDecar et al. 1995; Sol et al. 2002; Wolfe et al. 2002; Schimmel et al. 2003; Bastow et al. 2005; Benoit et al. 2006; Lees et al. 2007; Schmid et al. 2008, Bastow et al.2008; West et al. 2009; Rocha et al. 2011). In this method, traveltime relative residuals of telesseismic waves are inverted simultaneously for three-dimensional velocity structure, earthquake relocations, and station terms. 
The relative residuals are the difference between the observed time, obtained by visual picking of the seismograms, and the theoretical time (calculated time) related to the average model of the Earth (in this work we used IASP91 model - Kenneth and Engdahl, 1991). The mean travel time residual per event has been removed in order to decrease effects of the source and path errors related to influences outside of the study volume. The station terms are used to absorb systematic time contributions caused by local shallow heterogeneities, and earthquake relocations are used to take account earthquake mis-locations that can be induce a trend in time measured. In order to refine the arrivals picking, we used the cross-correlation method Multi-Channel Phase Cross Correlation (MCPCC), developed by Schimmel et al. (2003). Details about the method and the data processing procedure can be obtained in VanDecar et al. (1995), Schimmel at al. (2003) and Rocha et al. (2011).

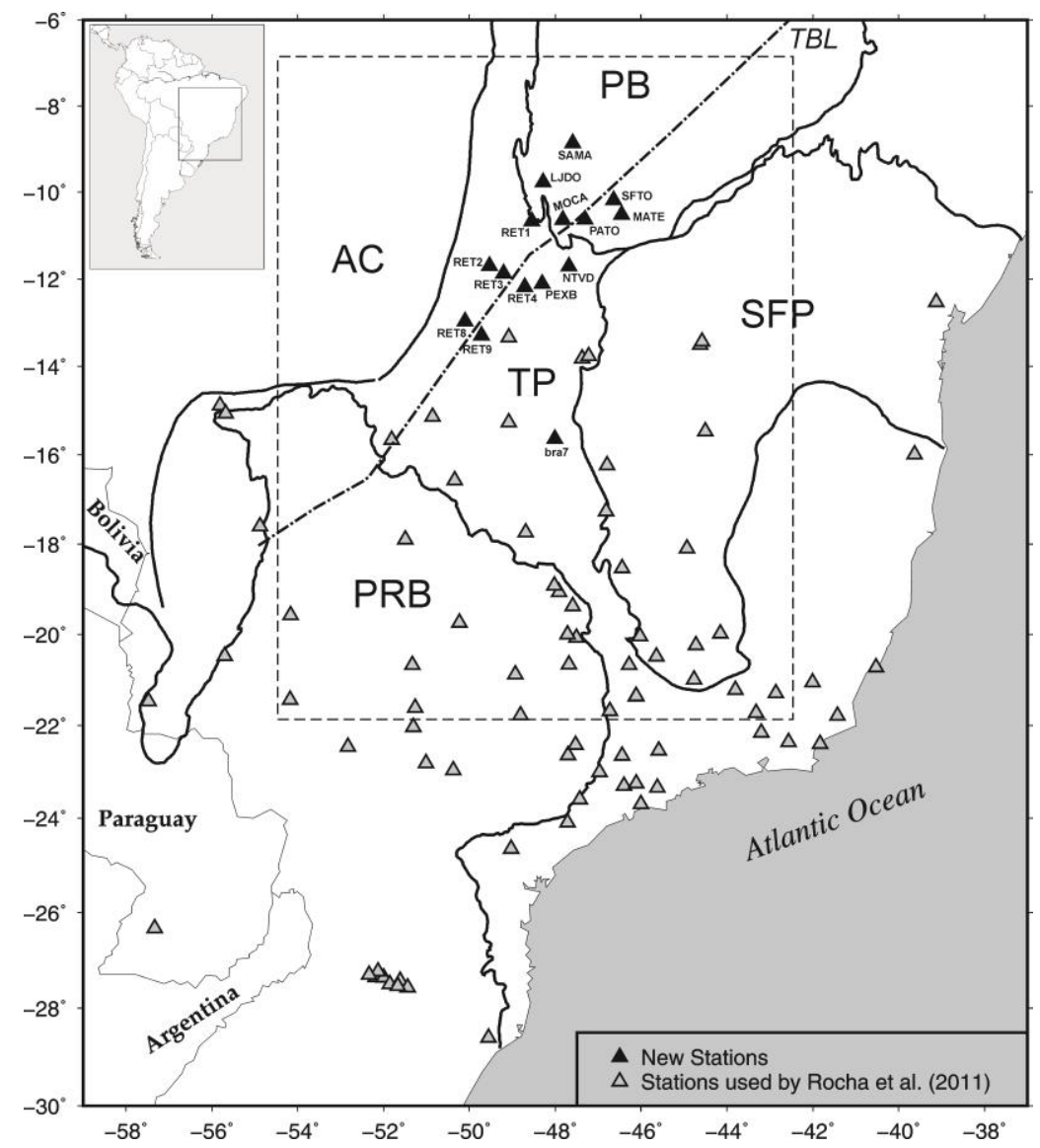

Figure 1: Study area with distribution of stations. Black triangles are new stations and grey triangles are old station used by Rocha et al. (2011). Dashed rectangle is the interpreted area. The solid lines in gray and black are the boundaries of states and geological provinces, respectively. Dashed and dotted line is the Transbrasiliano Lineament (TBL). PRB Paraná Basin; PB - Parnaíba Basin; TP - Tocantins Province; SFP - San Franciscan Craton; AC - Amazonian Craton.

The parameter model has been discretized in a dense grid of knots interpolated with splines under tension (Cline, 1981, Neele et al. 1993). This interpolation scheme provides a smooth slowness distribution and therefore permits an accurate ray tracing. The grid is composed of of 64,260 knots, knots in depth (depths between $0-1400 \mathrm{~km}$ ), 45 knots in latitude (latitudes between $-2830^{\circ}$ and $-10^{\circ}$ ) and 51 knots in longitude (longitudes between $-59^{\circ}$ and $-37^{\circ}$ ). In the central region of the model (25-15우 $53-40^{\circ} \mathrm{W}$; $0-500 \mathrm{~km}$ depth), the horizontal and vertical knot spacing is $1 / 3$ degrees and $33 \mathrm{~km}$, respectively. The knot spacing increases outside this region to 0.5 degree and $50 \mathrm{~km}$ in an intermediate volume, and to 1 degree and $100 \mathrm{~km}$ outside this intermediate volume. The parameterization extends outside the area of the stations network to minimize the mapping of noise and inconsistencies as unrealistic structures into the central area that will be interpreted.

\section{Results and Discussion}

Our results are velocity perturbations related to a reference model IASPEI91 (Kenneth and Engdahl, 1991). The anomalies represents mainly lateral heterogeneities in the model, where high-velocities are indicated by cold colors and low-velocities by hot colors. Areas without data are shown in black.

After installation of the new stations in the Tocantins Province, and South portion of Parnaíba Basin, was possible to observe a low-velocity elongated in the NESW direction (Figure 2) according with the trend of the Tranbrasiliano Lineament. This lineament is 
accompanied by a high seismicity, mainly in its central boundary of the Parnaíba Basin, which is practically aseismic. The low-velocity anomaly seems to be divided from this region, and apparently tends to contour the surface limits of the Parnaíba Basin. Is possible that the two branches of the low-velocity anomaly match the boundaries between the Basin basement and the surround tectonic blocks, explaining the seismicity absence in that region.

In this way, we could interpret the low-velocity anomaly as a thin lithosphere, with a consequent asthenosphere rising. Thus, the low-velocities in Tocantins Province could be representing a weakness region, causing the Tranbrasiliano Lineament reactivation. Unfortunately, no data is available in the Parnaiba Basin to confirm the existence of its basement.

In Figure 3 we show the vertical tomographic profile ZZ' (Figure 3c) indicated in Figure 2, a model proposed to explain the inhomogeneous seismicity in the EW direction in Central Brazil (Figure 3b), based our results and in the model proposed by Soares et al. (2006); and the cumulative event number over a range of $200 \mathrm{~km}$ width, centered in the profile Z-Z' (Figure 3a).

We can observe that the most seismic event occur in over the low-velocity anomaly. Some events occur in São Francisco craton, according to the diffusive portion. This seismicity reduces significantly at the

characteristic of the intraplate seismicity (Zoback, 1992). If the South American Platform was formed by a single continental block probably still exist seismicity, however, this would be diffusive as occurs in São Francisco craton. As this is not the case, with the existence of a region of weakness in the Tocantins province, it is expected that efforts, distributed across all South American Platform, can be relieved in the weakest region.

Figure $3 \mathrm{~b}$ is a model of the stress concentration along of the Z-Z' profile. The schematic depth distribution of the crust and upper- and lower mantle was based in the results of Soares et al. (2006). In this model, the depth distribution of the regional stress (blue arrows) in thinner lithosphere is different than thicker lithosphere. In thicker lithosphere most part of the stress is concentrated in the upper mantle, while in regions of lithospheric thinning is concentrated in the crust, giving conditions for occurrence of the seismic events.

Assumpção \& Sacek (2013) based in gravity results and modeling, proposed that the causes of the seismicity in the Tocantins Province is the flexural deformation. The arguments presented by then are strong, but we believe, based in our result, that the combining of weak zones, caused by lithospheric thinning, and stress concentration, have a significant influence in the causes of the seismicity in Central Brazil.

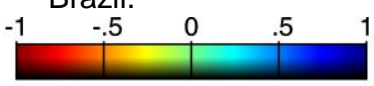

$$
0150 \mathrm{~km} \quad \text { P-wave velocity anomaly (\%) }
$$

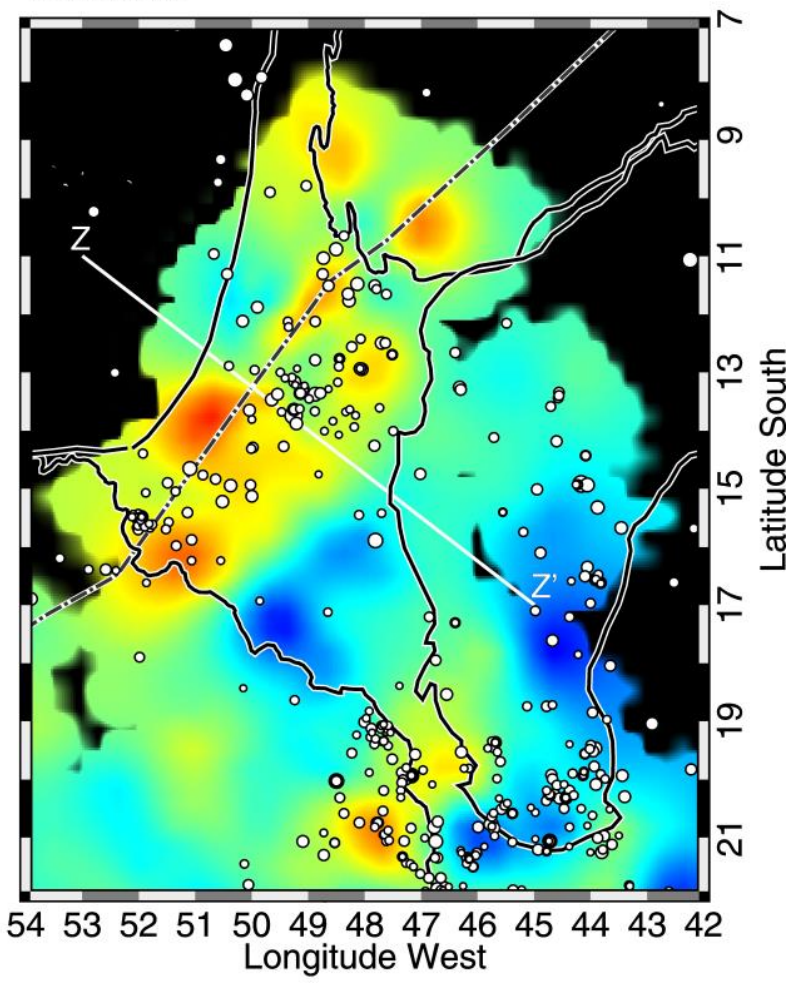

Figure 2: Tomographic horizontal image at $150 \mathrm{~km}$ depth, and the seismicity of Central Brazil. The thick lines indicate geological boundaries and the white circles represent the epicenter. The dashed-dotted line is the Transbrasiliano Lineament. 

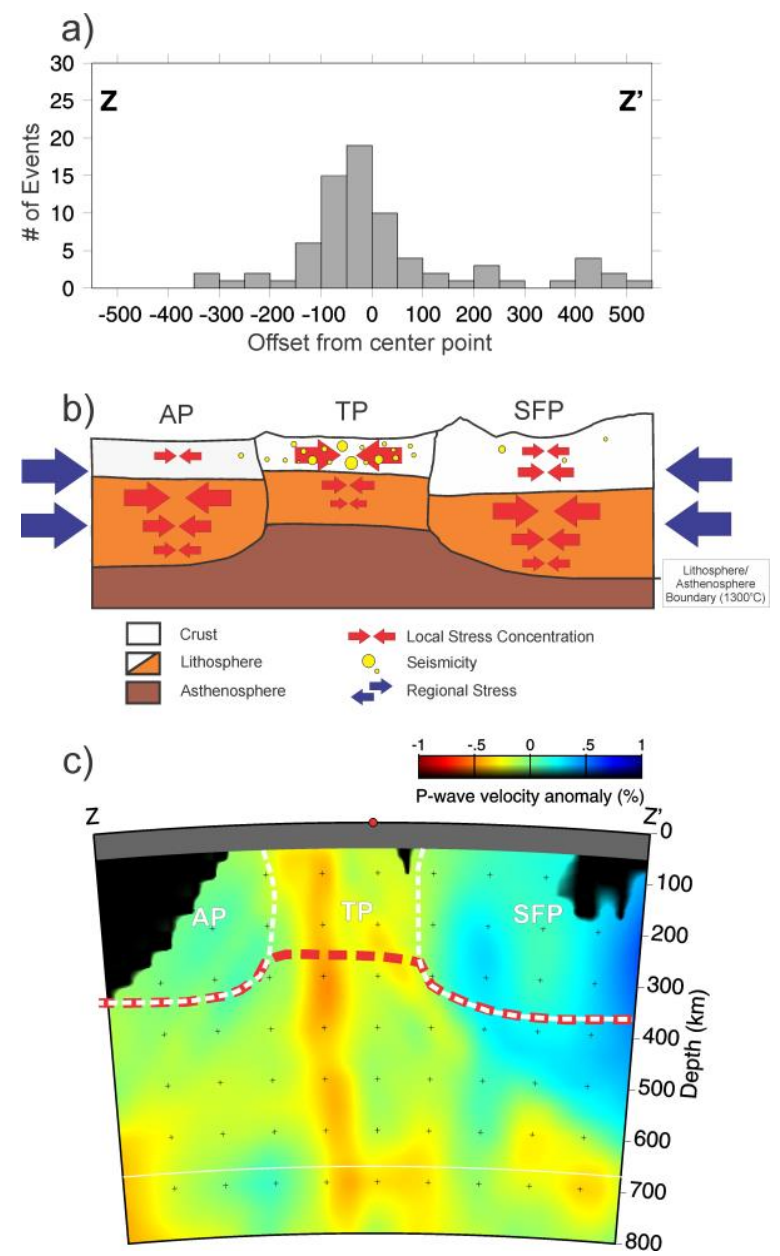

Figure 3 - Comparison of the P-wave tomographic results with seismicity distribution along the vertical cross section Z-Z' showed in Figure 2. (a) Epicenter distribution in Z-Z' profile. (b) Proposed model to explain the inhomogeneous epicenter distribution in Central Brazil (based in Soares et al., 2006). (c) P-wave tomography vertical profile (Z-Z') crossing Tocantins Province. Red dashed line cross section represents the Lithosphere-Asthenosphere Boundary (LAB).

\section{Conclusions}

In the South American Platform, tomographic lowvelocity anomalies coincide with relative high seismicity, mainly in Central Brazil. These low-velocity anomalies must be indicating region with lithospheric thinning.

The absence of the high seismicity in the cratonic regions can be related to the concentration of the most part of the diffusive regional stress in the upper mantle.

The almost total seismicity absence in the Parnaiba Basin can be related to existence of a cratonic nucleous that represents its basement. More stations need to be deployed in the Parnaiba Basin to confirm this assertion.

\section{Acknowledgments}

Authors thanks to Coordenação de Aperfeiçoamento de Pessoal de Nível Superior (CAPES) and the Project Instituto Nacional de Ciência e Tecnologia - Estudos Geotectônicos (INCT-ET) by the master's scholarship granted to author P. A. Azevedo. To CNPq by Research Productivity Grant provided to author R. Fuck, and also for the Petrobrás, by provide the resources for the development of this work.

\section{References}

Assumpção, M., Schimmel, M., Escalante, C., Barbosa, J. R., Rocha, M., Barros, L. V. (2004). Intraplate seismicity in SE Brazil: stress concentration in lithospheric thin spot. Geophys. J. Int. 159, 390-399.

Assumpção, M., \& Sacek, V. (2013). Intra-plate seismicity and flexural stresses in central Brazil. Geophysical Research Letters, 40(3), 487-491. doi:10.1002/grl.50142.

Bastow, I. D., Stuart, G. W., Kendall, J. M. \& Ebinger, C. J. (2005). Upper-mantle seismic structure in a region of incipient continental breakup: Northern Ethiopian rift, Geophys. J. Int., 162(2):479-493, doi: 10.1111/j.1365246X.2005.02666.x.

Bastow, I. D.; Nyblade, A. A.; Stuart, G. W.; Rooney, T. O. \& Benoit, M. H. (2008). Upper mantle seismic structure beneath the ethiopian hot spot: Rifting at the edge of the African low-velocity anomaly. Geochemistry, Geophysics, Geosystems, 9(12), doi:10.1029/2008GC002107. 
Benoit, M. H., Nyblade, A. A. \& VanDecar, J. C. (2006). Upper mantle $\mathrm{P}$-wave speed variations beneath Ethiopia and the origin of the Afar hotspot, Geology, v. 34; n 5: 329-332, doi: 10.1130/G22281.1.

Berrocal, J., Assumpção, M., Antezana, R., Dias Neto, C., Ortega, R., França, H., Veloso, J. A. (1984). Sismicidade do Brasil. Published by IAG/USP and Comissão Nacional de Energia Nuclear, Brazil, 320pp.

Cline, A. K. (1981). FITPACK - Software package for curve and surface fitting employing splines under tension. Department of Computer Sciences, University of Texas, Austin.

Coblentz, D. D., Richardson, R. M. (1996). Analysis of the South American intraplate stress field. J. Geophys. Res. 101 (B4), 8643-8657.

Cordani, U. G. \& Sato, K. (1999). Crustal evolution of the South American Platform, based on $\mathrm{Nd}$ isotopic systematics on granitoids rocks. Episodes, 22(3):167173.

Evans, J. R. \& Achauer, U. (1993). Teleseismic velocity tomography using the $\mathrm{ACH}$ method: theory and application to continental-scale studies, In: H. M. lyer e K. Hirahara eds. Seismic Tomography: Theory and Practice: Chapman and Hall, London, pp. 319-360.

Fernandes, E. P., Blum, M. L. A., Ribeiro, R. (1991). The Goiás seismic zone, a new approach. Extended Abstract. $35^{\circ}$ Congress Braz. Geol. Soc., vol. 2, pp. 553-558. Salvador/BA.

Johnston, A. C. (1989). The Seismicity of "Stable Continental Interiors". In: Gregersen, S., Basham, P.W., (Eds.), Earthquakes at North -Atlantic Passive Margins: Neotectonics and Post -Glacial Rebound. NATO ASI Ser. C, Mathematical and Physical Sciences, pp: 563579.

Kenner, S. J., Segal, P. (2000). A mechanical model for intraplate earthquakes: application to the New Madrid seismic zone. Science 289 (5488), 2329-2332.

Kenneth, B. L. N. e Engdahl, E. R. (1991). Travel times for global earthquakes location and phase identification. Geophysical Journal International, 105:429-465.

Lees, J. M., VanDecar, J., Gordeev, E., Ozerov, A., Brandon, M., Park, J. \& Levin, V. (2007). Three Dimensional Images of the Kamchatka-Pacific Plate Cusp. Volcanism and Subduction: The Kamchatka Region.Geophysical Monograph Series, 172, by the American Geophysical Union. 10.1029/172GM06.

Liu, L. and Zoback, M. D. (1997). Lithospheric strength and intraplate seismicity in the New Madrid seismic zone, Tectonics, 16 (4), 585-595, doi: 10.1029/97TC01467.

Mendiguren, J. A., Richter, F. M. (1978). On the origin of compressional intraplate stresses in South America. Phys. Earth Planet. Int. 16, 318-326.
Neele, F., Vandecar, J. \& Snieder, R. (1993). The use of $P$-wave amplitude data in a joint inversion with travel times for upper mantle velocity structure. J. Geophys. Res., 98, 12033-12054, ISSN: 01480227,

Rocha, M. P., Schimmel, M., \& Assumpção, M. (2011). Upper-mantle seismic structure beneath $\mathrm{SE}$ and Central Brazil from $\mathrm{P}$ - and S-wave regional traveltime tomography. Geophysical Journal International, 184(1), 268-286. doi:10.1111/j.1365-246X.2010.04831.x.

Schimmel, M.; Assumpção, M. \& VanDecar, J. C. (2003). Seismic velocity anomalies beneath SE Brazil from $P$ and $S$ wave travel time inversions. Journal of geophysical Research, 108(B4):1-13, doi:10.1029/2001JB000187.

Schmid, C., Van der Lee, S., VanDecar, J. C., Engdahl, E. R. \& Giardini, D. (2008). Three-dimensional S velocity of the Mantle in the Africa-Eurasia Plate boundary region from phase arrival times and regional waveforms, J. Geophys. Res., 113, B03306, B03306, 16 pp, doi:10.1029/2005JB004193.

Schulte, S., Mooney, W. D. (2005). An updated global earthquake catalogue for stable continental regions: reassessing the correlation with ancient rifts. Geophys. J. Int. 161, 707-721.

Soares, J. E., Berrocal, J., Fuck, R. a., Mooney, W. D., \& Ventura, D. B. R. (2006). Seismic characteristics of central Brazil crust and upper mantle: A deep seismic refraction study. Journal of Geophysical Research, 111(B12), B12302. doi:10.1029/2005JB003769

Sol, S., Thomsom, C. J., Kendall, J-M., White, D., VanDecar, J. C. \& Asudeh, I. (2002), Seismic tomographic images of the cratonic upper mantle beneath the Western Superior Province of the Canadian Shield - A remnant Archean slab?, Phys. Earth Planet. Inter., 34, 53-69, ISSN 0031-9201, doi: 10.1016/S0031-9201(02)00081-X

Sykes, L.R., (1978). Intraplate seismicity, reactivation of preexisting zones of weakness, alkaline magmatism, and other tectonism postdating continental fragmentation. Reviews of Geophysics and Space Physics 16, 621-688.

Talwani, P., (1989). Characteristic Features of Intraplate Earthquakes and the Models Proposed to Explain Them. In: Gregersen, S., Basham, P.W. (Eds.), earthquakes at North- Atlantic Passive Margins : Neotectonic and Post-Glacial Rebound. NATO ASI Ser. C, Mathematic and Physical Sciences, pp: 563579.

Talwani, P., Rajendran, K., (1991). Some Seismological and Geometric Features of Intraplate Earthquakes. Tectonophysics, Vol.186, pp: 19-41.

VanDecar, J. C.; James, D. E. \& Assumpção, M. (1995). Seismic evidence for a fossil mantle plume beneath South America and implications for plate driving forces. Nature, 378:25-31, doi:10.1038/378025a0. 
West, J., Fouch, M., Roth, J. \& Elkins-Tanton, L. (2009). Vertical mantle flow associated with a lithospheric drip beneath the Great Basin, Nature Geoscience, 2(6), 439-444, doi:10.1038/ngeo526.

Wolfe, C., Bjarnason, I., VanDecar, J. \& Solomon, S. (2002). Assessing the depth resolution of tomographic models of upper mantle structure beneath Iceland. Geophys. Res. Lett. 29(2), 1015, 1-4, doi:10.1029/2001GL013657.

Zhang, Z. J., Wang, Y. H., Chen, Y., Tian, X.B., Houseman, G., Wang, E., Teng, J. W. (2009). Crustal structure across Longmenshan fault belt from passive source seismic profiling. Geophys. Res. Lett. 36, L17310. doi:10.1029/2009GL039580.

Zoback, M. L. (1992). Stress field constraints on intraplate seismicity in Eastern North America. J. Geophys. Res., 87, 11761-11782. 